\title{
Democracy and Development in Asia
}

\author{
Daw Aung San Suu Kyi
}

It is a pleasure and an honor to be addressing all of you today. First of all, I must thank the University for conferring this honorary degree on me, and I hope that I will be able to do enough for education in Burma to deserve such an honor. There is much that we have to do and there is much support and help that we need from our friends.

The subject on which I have been asked to speak today is development and democracy in Asia. This is of course a vast subject and would require several volumes if one were to treat it thoroughly. But I would like to talk mainly about the direction in which I would like my country, as a nation in Asia, to go in the matter of development and democracy. Democracy is a very broad word, it's a very broad subject, and it can be subjected to many different interpretations. But basic to our ideas of democracy are the ideas of freedom, justice, and security. I have often said that democracy has to strike a healthy balance between freedom and security because all human beings want freedom and at the same time, they want security. They do not want to sacrifice one for the other. Many authoritarian regimes emphasize security and deprive people of their freedom. But on the other hand, unlimited freedom, which will threaten the security of the citizens, is not what we would wish for. So, a healthy balance between freedom and security upheld by the rule of law is what we would aim towards. Within such a context, I believe our country can develop and become the kind of nation that we have always hoped that it will be.

Many years ago, that is to say in 1948, we achieved independence from the British colonial government. Before that, our freedom fighters-the fighters for independence in Burma-always spoke of their desire to be able to shape the destiny of their nation. They did not want the destiny of the nation to be shaped by others, by foreign powers. They wanted to be the ones to decide what shape the nation should take. And it was with this call for our right to shape the destiny of our nation that we became independent. But not too long after, that is to say,

This lecture was delivered on the occasion of the Conferral of an Honorary Degree of Doctor of Education from Seoul National University on February 1, 2013.

(C) 2013 The Institute for Peace and Unification Studies, Seoul National University

E-ISSN 2288-2707 Print ISSN 2288-2693 
less than two decades after we achieved independence, Burma fell under military rule, and during that time the people of our country did not have an opportunity to take part in the shaping of the destiny of their nation because that was taken over entirely by the rulers. So for us, democracy means, at this moment, the right to shape the destiny of our nation as the fathers of our independence wanted us to be able to do. And I think this would be true of all the nations of Asia who hope to achieve democracy.

Democracy in Asia is shaped to a certain extent by our customs, by our traditions, and by our histories. I read a book many years ago before the 1988 uprising for democracy in Burma where it was pointed out that, among the nations of Asia, Burma would have the greatest difficulty in achieving democracy because of our social values. I was amazed at how perceptive the writer was. $\mathrm{He}$ pointed out some of the drawbacks in our social values that would militate against the establishment of democracy. Other countries were discussed including Korea and the point was made that, although he did not put it specifically, it was implied that all these other nations would probably achieve democracy before Burma did, and this is true. This has turned out to be true. We have not yet achieved democracy -we are just beginning to start out on the road. This is a point that I have to keep repeating, that Burma is still trying to achieve democracy. We are preparing the ground, but we have not yet planted the seed of democracy firmly in our soil. And as we work towards it, we obviously look to the other nations of Asia to find out what we can learn from them. The one advantage of being behind everybody else is that we can learn from their mistakes as well as their successes.

What I find in travelling abroad is that there has been tremendous material development in the world over. When I went to Europe last year-I first went to Thailand for a few days and then I went to Europe last June; it was the first time in over 25 years that I had traveled to developed countries-I found that those countries were richer than ever, wealthier than ever, and better off materially than they had ever been. It was a little of a surprise for me because I had heard on the radio about the economic downturn, the problems that were supposedly plaguing the affluent world. And yet, in spite of that, the Europe that I saw last year was noticeably wealthier than the Europe that I saw back in the early 1980s. This was the same for the United States of America. Obviously, it was the same for Thailand. Korea, I had never been before so this is my first visit to Korea, but I have no doubt that it is far wealthier now than it was in the early 1980s.

In spite of these material improvements, I did not feel downhearted for my country. I understand that we are behind everybody else in both democratic and economic development but it did not in any way worry me because I feel that this gives us an opportunity to follow the kind of path that will lead to the kind of nation that we would like to build. And the kind of nation that I would like to see my country turn out to be is one which emphasizes some of the human values which seems to me have been lost along the way to economic development. I 
know that it is not fashionable these days to talk about such values as compassion and kindness and harmony, but these are absolutely necessary for our world today. There is too much conflict and too much violence in our world and we need to do something about it. Especially the young people need to do something about it because it is their future, it is the world that they are going to be living in. The older people, we shall be leaving it soon with all its chaos to the young to cope with, so it is up to the young to make sure that development, whether politically, economically, or socially, would lead to its greater harmony rather than to its greater strife. I am not aware that technological developments have in any way lessened the possibility of conflict in our world. It is not technology that is going to decide what kind of world we are going to build. It is our human nature. It is our human will which will decide what kind of world we are able to build. So when we talk of democracy in Asia, I would like to talk about democracy with a more human face, with a kinder face, with a more responsible face-a democracy which is really meant to nurture people, not to help us get ahead in the roads to material development.

Too many people link democracy with economic development. They are those who say either that economic development is necessary for democracy or that democracy is necessary for economic development. But there is less said about how necessary democracy may be for human development, that is to say, for nurturing the better qualities in human nature. I do believe that we are capable of developing the better qualities in ourselves, otherwise we would not be here today; we would still be living in caves and clubbing each other to death. So we have improved, we have been able to become better human beings. But there has to be a sustained effort to keep improving our human situation, and democracy should be a means rather than an end. I do agree with those who say that democracy is not a perfect system, but it is the best that human beings have been able to develop so far. Best for what, is the question that we need to ask. Best for what? Best, in my opinion, it should be the best for building up a society that appeal to the best in human nature. Best should mean simply that, what appeals to the best in you, what appeals to the best in all of us. And that means linking responsibility with rights. Too often in a country like Burma where the people have been deprived of their rights for long decades, people think of democracy solely in terms of rights-what they expect to get from a democratic system-and very little about what they should give. And this is something that I have to keep reminding our people: That democracy entails responsibilities as well as rights, and that if we wish to enjoy our democratic rights, we have to be prepared to carry out our democratic responsibilities. And democratic responsibilities, taking the simple definition of democracy as rule of the people, mean responsible rule by people. So, each person must not only be involved in the responsible rule of the country, he or she must take responsibility for ruling himself or herself. In the end, unless we are all able to rule our own personal natures, we will not be able to 
contribute very much towards justice and balance in this world.

So, when I think of democracy in Asia, I think of the kind of democracy I would like to see in my own country and I have been greatly heartened by the reaction of our young people. Last year when we were campaigning for the by-elections in Burma, the greatest support for our party came from the young people and their enthusiasm, their aspirations, and their dedication to contributing towards what we were trying to do was truly encouraging. Some of them did not quite know how to help us, but they wanted to help; they wanted to help us to build the kind of nation that will be a true sanctuary for all of us, a nation that could be a true home. A home is a place where you feel safe, where you feel happy, where you feel confident that you belong. And this is the kind of home we want for all the peoples of Burma. We are a country of many ethnic nationalities. Whenever I speak of my country, I point out the fact that we are a union of many ethnic nationalities, but we are not yet a true union, neither are we a democratic union as well. And this is what we have to try to achieve. And we would like to learn from our neighbors in Asia, from other Asian democracies, how to achieve national harmony.

It is for this reason I am particularly pleased to be in Korea and to learn from the Korean people because they have been through the same kind of struggles that we have. They have had to struggle against military dictatorship and work to reestablish democratic government and also to achieve economic success. At the same time, the Koreans, more than perhaps many other peoples in the world, understand what inner conflict means, what divided people means, what it entails, what hardships, what heartbreaks, personally as well as nationally. And we are still a people divided because not all the ethnic nationalities of Burma have been able to come to an agreement. I always accept that the Burmese ethnic group, as the largest in the country, has the greatest responsibility. The greater your strength, whether numerically or materially, the greater your responsibility. And we have to work harder than any other ethnic nationality group to make sure that our country becomes the kind of democratic union which we have all longed for and which we must build up in order to repay the fathers of our independence for what they did to make our country a free nation in this world today.

Democracy is a learning process. In fact, life is a learning process, and I hope that this is something of which our young people are aware-that learning never comes to an end. Once you think that you have learned enough then I think it's trouble. You must always remember that there will never be a time when there is nothing left for you to learn. In this way, I feel that my country has much to learn but also that other countries have much to learn from us. We may be poor now; we may be economically deprived. At the Special Olympics, I mentioned the fact that in some ways you can say that our country has suffered from social and political disabilities for the last five decades because the first military regime was established in 1962. So five decades of social and political disablement is a 
large problem for us to cope with. Yet in spite of this, I think you will have much to learn if you come to Burma and you study the situation. You will be able to see the drawbacks that we have suffered from over the years and at the same time perhaps you will be able to see some of the values that you have lost along the road to development. There are some values which I would not like to see our people to lose; I would like to preserve some of our values. But this cannot be done artificially. This can be done only with the willing participation of the people. They themselves must believe that certain values need to be preserved and they themselves must want to preserve these values. In this way, I would like to take my country forward to the kind of democracy which will lead to a kinder human society.

I have said quite often that my experiences over the last two decades have convinced me that the most valuable quality human beings can possess is kindness-kindness which costs nothing, but which people are so reluctant to give; I do not know why. Kindness costs none of us anything and yet it is the great gift you can give to another human being. Kindness is the ability to recognize other's need and to do whatever you can to fulfill that need, not because you expect anything in return but because it is your joy to give. So, if I have to put in a nutshell what kind of democracy I would like to see for my country, I would like to say, I want to see a giving kind of democracy. The kind of democracy where people put emphasis on how much they can give and on the joy of giving rather than how much they can get and on the joy of receiving. And I hope that this is the kind of democracy that our Asian nations will aspire towards. I have noticed with pleasure and with genuine gratitude that some of the richer countries are beginning to adopt more and more humanitarian values. They are beginning to realize that material wealth is not all-that true wealth lies only in human nature. And unless we can build a better, richer human nature among us, all the material development in the world is not going to get us greater happiness.

I think this is the time limit I have been given. I am very punctual, I have great respect for time because I believe that respecting time means respecting other people's time. So I would like to thank all of you for giving me this opportunity to speak to you and also I would like to say that while I am talking about the higher values of human nature, I also have a very practical political side to me, and one of the aims of my country which is trying to establish democracy in Burma is to make amendments to the constitution that will help us to win the elections in 2015 , so I hope you will all help. Thank you very much.

\section{[Q \& A]}

Q: Thank you very much. My question is, what is your plan for ethnic groups in Burma? People are suffering because of the central government. 
A: There are many ethnic groups in Burma who are suffering, not just because of the central government but because our country is underdeveloped. But the conflict between all different ethnic groups will have to be resolved through the establishment of mutual understanding and mutual trust and respect. I think it is incumbent on all ethnic groups to see what they themselves can do to contribute towards national harmony and reconciliation. I think that the Burmese ethnic group must take responsibility for what they can do and they must try their best to add to national harmony and reconciliation. At the same time, all other ethnic groups must take the same kind of attitude. Each group must question what they can do rather than what can the other one do, what can the other groups do. If we were to take this responsibility for our own actions, I think we will come to reconciliation quicker. But as to humanitarian suffering, the National League for Democracy has always spoken up for humanitarian access to all the troubled areas. We can only speak up, we can only ask for it-we are not the government, we are not in the position to enable humanitarian groups and organizations to go to the conflict areas. We can only recommend and persuade.

Q: Hello, I would like to know if you have any pearls of wisdom for Myanmar students who are studying abroad, like what they can do for the development of their country.

A: Well, first of all, I think they have to find out what they are capable of doing, for example, if it is education that interests them, there are many things they can do to help education in Burma. It's a matter of what the students' strengths are. Whatever their strengths are, they can use to contribute towards the development of our country. But first, they have to have the will to help. Burmese students know how we say in Buddhism that the root to success starts with the willstudents have to have the will to help, and they must decide that they will help in every way possible. If they really want to help, they will be able to find a way. Since I am not aware of what the students' qualifications are, it is difficult for me to say what each one can do, but I would like to urge the students as I always have to urge Burmese students, first of all, to be united among themselves, not to fall out, not to quarrel, not to bicker. I think Burmese students have a tendency to fall out among themselves and this is not a tendency that I would like to encourage, so please start by cultivating solidarity and understanding between themselves. With that they can help our country a lot.

Q: Hi, I am a Seoul National University student and my major is Biological Science. My question is, what would you like to focus on most for the economic development of Burma?

A: Well, if we look at the economy, one of the things that concern me most about our economy is the fact that there are so many unemployed young. And for me, in order to set our economy up and also to put our country on the wide road, we 
must find work for the young. I've said very often that what is worrying is not joblessness but hopelessness. We don't want our young people to get to the stage where they lose hope because they have been jobless for so long. So job creation to me is the most important development I would like to see in our economy.

Q: I'm Nigerian, currently at the Graduate School of International Studies. My major is International Development Policy. Based on your wealth of experience, I would like to know what your advice is to the youths, with regards to tolerance, perseverance, and hard work as future leaders of tomorrow.

A: I think tolerance is very important to begin with. There is one thing that I would like to talk about while I am with young people and this is something I have discussed very often with my meetings with young people. The fact that nowadays, because of technological advances, young people tend to link up with those of like minds. For example, I understand that on the net people always seek out people who share their own opinions and this creates polarization. So, tolerance has to be based on acceptance of differences, and not just accepting but also valuing differences. You must learn to value people for the way in which they are different from us, not just for the way in which they are same as us. For example, when I am in Korea I would like to eat as much Korean food as possible. There is no point in indulging in hamburgers-I can do that anywhere in the world. You have to respect and value other peoples' differences and this is what tolerance is all about. I consider tolerance very important because that is what will help us to create a harmonious world. Whereas perseverance and hard work, that can be for yourself, you can work very hard to better yourself and you can also work very hard to impose your values upon other people. So, hard work and perseverance can be misused. The Buddhists have a saying that you can overdo everything except awareness. You can't overdo awareness, but everything else can be overdone-hard work, perseverance, even wisdom can be overdone. But awareness which makes you understand, not just other peoples' weaknesses and strengths, but also your own weaknesses and strengths, that can never be overdone. And I think that is at the root of tolerance.

Q: I am delighted and very honored to get to see you this close, I think all of the audience shares my same sentiment. If I may, I would like to ask you two questions. You went through so many hardships in your life beyond anybody's imagination. I was wondering what held you through those difficult times or who. That is my first question. My second question is, I am a professor of International Relations. Could you say something to the students, female students especially, who aspire to become diplomats, public officials, and NGO (non-governmental organization) activists?

A: Well, first of all, I think the reason why I was able to overcome what you call hardships is because I never looked upon them as hardships. In fact, I don't think 
my life was hard at all compared to my colleagues who were thrown into prison. I have to keep reminding people that I was kept under house arrest, but house arrest simply means staying in your own house. Of course it deprived me of the company of others since I was not allowed to go out-the first six years of house arrest I was kept completely on my own-but I did not find it a hardship. I think I was lucky in that my education gave me enough inner resources for me to be able to cope with isolation, so what people saw as hardships I did not see as hardships at all. I just saw those as challenges to be met as I went along the path I had chosen for myself. Now for all the girls who are studying international relations and who want to be activists and NGOs, I think they have to have a goal. You should not be an activist for the sake of being an activist. You have to have a goal. What do you hope to achieve by your activism and what do you hope to achieve by working for an NGO? You have to know what your ends are and then of course you choose your means, and the means have to be tailored to harmonize with the ends that you wish to achieve. I do not think that you can separate the ends from the means. There are some who say that any means to achieve the ends that you want, but quite often when you use the wrong means, you find that when you do reach the goal you hoped to reach, it has become distorted and it is not quite what you had hoped for. So, I would like to say to all those girls who want to become activists or who want to be members of NGOs, what do they hope to achieve? What is it that they wish to achieve? Then they must decide how they handle the professions that they take.

Q: Hello Dr. Suu Kyi, welcome to Seoul National University. I am studying International Commerce. Your career path and your life itself is a living inspiration to many, and I wonder if you have your very own source of inspiration or a female role-model.

A: Well, I have had a number of sources of inspiration. In fact, when you think of it, every human being can inspire you in some way or the other, either negatively or positively. I mean, you can decide that "I don't want to be like that person," and this is itself a kind of inspiration. Or there may be qualities to just ordinary people around you that you admire and respect and who can help you to be a better person. But if you are thinking in terms of public personalities, of course my father has been a tremendous influence on me, because he is our national leader and I was always taught by my mother, who always taught me in a very simple way, that when she talked about my father she always emphasized his honesty. And so I am a great believer in honesty in politics, which is, I think, considered a little outdated these days. But I think honesty in politics is essential. There are many people who say that this is idealistic and that this shows lack of maturity in politics, but the longer I have been engaged in politics, the more I believe that honesty is truly the best policy. Honesty with your public-you don't have to reveal all, you can't reveal all, but because the world is such, human nature is such 
that people will trample on you if you reveal all that you feel or suffer from. But I believe that whatever you say to the public it has to be honest. You need not make them promises that you cannot keep. That is the one thing that I dislike most about political leaders and other leaders-when they make easy promises, and then they just as easily say that "sorry, that was not possible." I cannot understand this at all. I find it very difficult breaking my word. I have had to, very very few times in my life, but the few times in my life that I have had to break my word, I have done it with great difficulty and I have very suffered for doing it-suffered from guilt, suffered from the sense that I have done wrong. Because you should not mislead people. I think it is the cruelest thing in the world to give people hope when you don't really intend to do anything about it. So, I believe very much in honesty in politics, and people like my father, people like Gandhi, were public figures who believed in personal as well as public honesty.

Q: Thank you so much for this opportunity. As you just mentioned just before, keeping a promise is most important. In 1994, a cease-fire agreement was made between the government and the Kachin organization group in Myanmar, but it was broken. Because the government didn't keep their promise, still the fighting continues which has been very violent and has brought great suffering to the Kachin tribe people. Many of the Kachin tribe escaped to the Chinese border area, and also education-wise, economically, socially, emotionally, the conflict has been interrupting all the lives of our people as this violence is in our homeland. So the people have this great hope that things will change. I would like to ask you what the hindrance was to make the government break their cease-fire agreement made in 1994 with the Kachin organizations, and also where they can find the hope, real peace, and justice for the Kachin people.

A: To begin with, we don't know what promises were made between the Kachin and the military government. You must remember that at the time these promises were made, at the time when the cease-fires were agreed upon, I was under house-arrest and the great majority of the leaders of the NLD were in jail. So, we were not part of the promises, we were not part of the agreements, we did not really know what they really were. I understand that they all broke down in 2010 before the elections because of the insistence of the Burmese government that the Kachine Independence Army (KIA) disarm before the elections. This is something that they must sort out, and when I say the KIA, must sort out with those with whom the promises were made. From our point of view, we want to do everything we can to help along the peace process. People have asked me why I am not involved. A peace process is not something in which you could just get yourself involved. They have to be invited by the parties concerned. It is not as simple as saying I want to be involved. I have in fact written an open letter saying that my services are available to all those who wish me to participate in the peace process, but my party and I have to be asked by those concerned. We can make 
comments, we can criticize the situation, but do we really help by doing that? This is something that I always think about. It's very easy for us to criticize what other people are doing. By criticizing, are we actually helping? Or are we making the process of negotiation more difficult? This is a question that we have to keep asking all the time. But should the Kachin people and the government wish us to be involved in the peace process, we would not hesitate to take part in it. In the meantime, what we would like to emphasize is the need for humanitarian access to all the displaced persons because it is the civilians who suffer the most, it is the unarmed common people who suffer most when armed groups get into a situation of conflict. This is something we should all remember: That conflict requires two sides and usually, both sides to a conflict are armed and the ones who really suffer are the ones caught in between, particularly the women and children. So I hope the Kachins take care of their women and children, and humanitarian groups try to get access to them as quickly as possible.

Q: I am from Uganda. We are very inspired by what your story tell us, especially the women in our country. I have a question. When President Obama paid a courtesy call at your residence, you said that the Burmese or other nations should not be taken by the mirage that is going on because you thought that their democracy has not reached the point. To what extent to do you think, or how would we evaluate our country that it reached a certain level to be categorized as fully or partially democratized? Also, I have been here in Korea for some time, and Korea is a homogeneous country of one people, but most African countries have very many tribes and this has derailed the democracy process. On the issue of tribalism and countries with many ethnic groups, what advice do you have to such countries which have very many ethnic groups who fight with each other and make the door to democracy be shut?

A: Before I answer your question, I would like to thank you and also the students of Nigeria because one of the things I discovered in my trips abroad was how supportive the peoples of Africa were in our movement in Burma. That gave us a tremendous surprise because I had not known that there was so much awareness of the situation in our country among the people of Africa and the Middle East. But wherever I travelled in Europe, I kept meeting Africans and Middle Easterners who would come up to me and speak words of support. So, I would like to take this opportunity to thank all of you. Talking about a mirage and when would I consider a country to have achieved democratization-there are two sides to your question: One is when I would consider that Burma really is where it should be and that this is not just a mirage, and is of course about tribal conflicts and about dissension within different countries. Now, with regard to when I would consider the democratization process in Burma to have advanced satisfactorily, this would be when the common people in Burma feel a change in their lives. I think if you go to Burma now and you ask ordinary people whether 
their lives had changed since 2010, the great majority of them would say no. They live in hope but they haven't really experienced change in their lives. And I think the common people will have had to experience real positive change before we can say that the democratization process is going along satisfactorily. Now, with regard to dissension within our own countries, with regard to the fact that there is conflict between different tribes, different races, different ethnic groups, I think it all stems from fear of what is different from you. Hate is very closely linked to fear. If you hate anybody or anything, this is something that you must ask yourself honestly. If you feel you hate something or somebody, you must ask yourself, don't you really fear that thing or that person? Is there not something that you fear about that person that you hate? For example, do you fear that he or she will do better than you, or that he or she will get what you are trying to get, or that he or she will somehow harm you? Is it possible to hate somebody that you do not fear? This is a question that I would like all of you to ask yourselves. And then the question is, what is it that you fear? Usually, people fear what is unfamiliar, what is strange, what is different, what they do not understand. Then it's a matter of getting yourself to understand what you don't understand so that you will be able to get over that fear, that difference, that strangeness. And then you will be able to get over that hate. It's the same with all conflicts. People get into situations of conflict because they feel threatened. To feel threatened is to feel fear. Some say that offensive is the best defense, which simply means that they feel threatened and they think that they had better take action before the other side does so that they have the upper-hand. So with all the lack of unity from which we suffer, basic to it I think is the fear of what is strange to you, what is not familiar to you, fear of what is different from you and your values. So, we were talking about whether tolerance is more important or perseverance or hard work, and I said tolerance because that is the way in which you get rid of your fear and your hatred, and that will also help you to resolve the problems of disunity and conflict. That is what I believe. Conflict resolution begins from inside, and then only you can work outwards.

\footnotetext{
Daw Aung San Suu Kyi is a Burmese opposition politician and the Chairperson of the National League for Democracy in Burma. She received a doctoral degree at the School of Oriental and African Studies, University of London. She was awarded the Nobel Peace Prize in 1991 for her nonviolent struggle for democracy and human rights. She remained under house arrest in Burma more than fifteen years from 1989 until her most recent release in 2010. She is now a member of the Pyithu Hluttaw, the lower house of the Burmese parliament, representing the constituency of Kawhmu.
} 
